\title{
Revisiting cognitive tools from a social and motivational perspective
}

\section{Xun Ge}

The University of Oklahoma, USA

\author{
Murat Turk \\ The University of Oklahoma, USA \\ Woei Hung \\ The University of North Dakota USA
}

\begin{abstract}
The concept of computers as cognitive tools has been revisited to provide insight into the motivational and social dimension in light of the emerging technologies. Central to this concept are the two opposing philosophical views: learning from technology (amplification view of technology) versus learning with technology (constructivist view of technology). A literature review is provided on the paradigm shift in educational technologies from the "learning from paradigm" to the "learning with" paradigm. While the literature review shows powerful affordances of emerging technologies in engaging community of learners in knowledge construction and building, a critical analysis also indicates a significant gap in the traditional conception of cognitive tools, that is, a lack of research in the motivational and social dimension. Therefore, the purpose of this study was to investigate the motivational and social dimensions of cognitive tools in the context of emerging technologies, with the substantiation of empirical evidence from the literature.
\end{abstract}

\section{Introduction}

In the past few decades, efforts have been made to understand the impact of educational technologies on student learning. Research on cognitive tools is an example of such an effort (Kim, 2012). Cognitive tools, or mindtools, as Jonassen and Carr (2000) phrased them, are tools that enable learners to engage in critical thinking, knowledge representation, and meaning-making processes (Jonassen, 1995). They are tools such as computer applications (e.g., spreadsheet, databases, semantic networking tools) which students can learn with, rather than instructional programs which students learn from (Jonassen, 1995). Interest in studying cognitive tools or mindtools (Lajoie, 2000; Lajoie \& Derry, 1993) started in the late 1980s and early 1990s, and by the 2000s we had gained more in-depth understanding of computers and their cognitive functions, primarily represented by the works of Lajoie (2000) and Jonassen (2000).

Since the 1990s, there has been an exponential growth in emerging technologies that have extended beyond personal computers, from Google classrooms to social media tools, to virtual reality software, and to digital media production kits. Emerging technologies seems to be a fuzzy term that has been defined in various ways in the literature (Veletsianos, 2010). In this article, the term emerging technologies refers to current and newly developed technologies, which can be any digital technological tools, including mobile phone apps, and Web 2.0 social media and networking tools that have the potential for affording educational cognitive partnerships. There has been a call recently to revisit the traditional conceptualisation of cognitive tools since the affordances of the emerging technologies are no longer restricted to providing only cognitive and metacognitive support to learners. Rather, emerging technologies can enrich cognitive affordance with their capacity for offering social and motivational support for learners. However, there has been little discussion about the social and motivational aspects of cognitive tools, or the role of cognitive tools in mediating motivation, in the traditional conceptualisation.

Therefore, the purpose of this study was to explore the social and motivational affordances of the cognitive tools in mediating learning. In this article, we first provide a synthesis of the literature on the historical background of computers as cognitive tools, followed by an examination of the evolution of computer systems and their impact on a paradigm shift in education. Then, we report a critical analysis of the literature in an attempt to provide empirical evidence on how emerging technologies offer motivation and social support in addition to cognitive support. This article ends with a discussion of the implications for the future development of theory, research, and practice. 


\section{Background: Computers as cognitive tools}

\section{The rise of cognitive tools}

Research on human cognition and memory has long shown that humans have limited working memory capacity, for example, the principle of 7+/-2 (Miller, 1956; Sweller, 1988; Ward \& Sweller, 1990). However, with technology, we are able to perform tasks that are beyond our natural cognitive capacity due to its function to reduce cognitive load (Sweller, 1988). Technology can function as an aid to free us from having to perform lower-level cognitive tasks (e.g., a calculator, a computer) and utilise our precious cognitive resources to tackle higher-order cognitive tasks (e.g., interpreting the results of a statistical test). Pea (1985) called such technology an extension of the mind. However, researchers (Pea, 1985; Salomon \& Perkins, 1989) argued three decades ago that technology should not be limited to serving as an amplifier of the mind (Pea, 1985), but serve as a cognitive tool to help learners reorganise their mental functioning. Although the functions of these two types of cognitive tools are not mutually exclusive, the latter use of tools should be emphasised. In the 1990s, Jonassen (1996) and Lajoie and Derry (1993) became the main advocates for the use of technology as cognitive tools to scaffold students' cognitive processing. Though termed differently, both cognitive tools (Lajoie, 2000) and mindtools (Jonassen, 2000) are concepts coined to describe technologies used to create student-centred, active-learning environments by providing aid for cognitive and metacognitive processing, such as information processing, knowledge construction, knowledge organisation, knowledge representation, critical thinking, reflective thinking, and problemsolving (Jonassen, 1995; Jonassen \& Reeves, 1996). Jonassen particularly advocated the role of cognitive tools in serving as intellectual partners (Salomon, Perkins, \& Globerson, 1991) with learners.

Jonassen (2000) and Jonassen and Carr (2000) identified a number of categories of cognitive tools which students can learn with:

- semantic organisation mindtools (e.g., databases and concept maps) to help students integrate knowledge by visually representing the patterns and interrelationships among the concepts to be learned;

- dynamic modelling mindtools (e.g., spreadsheets, expert systems, system modelling tools, and microworlds) to help students critically examine and represent the interrelationships among variables within a system in various forms through constructing simulations;

- knowledge construction mindtools to guide students in actively searching, examining, interpreting, and integrating relevant information to construct a comprehensive and coherent knowledge base;

- conversation mindtools to enable students to communicate effectively and co-construct knowledge through exchanging ideas and engaging in meaningful social interactions.

These are the tools that students can learn with and creatively use to build and construct knowledge. The underlying theoretical basis and the practical applications of cognitive tools are described by Jonassen (1990) and Lajoie and Derry (1993) and supported by sociocultural theories (Vygotsky, 1978).

\section{A paradigm shift from learning from to learning with technology}

As discussed above, students can benefit from cognitive tools in different ways: learning from technology and learning with technology (Jonassen \& Reeves, 1996), which reflects two different philosophical perspectives. The "learning from" perspective reflects the transmissive view of learning. It contends that there is absolute truth and reality external to the learner's mind, and students' responsibility is to learn from a tutor or teacher who prescribes what to learn and how to learn (Jonassen, 1991). On the contrary, the "learning with" perspective reflects constructivist views of learning. This view insists that knowledge cannot be imparted to students, who can only gain learning experience through actively constructing knowledge (Jonassen, 1991).

Educational technologies have undergone evolutionary phases, from the audiovisual instruction movement in the 1950s, the computer-assisted instruction (CAI) systems in the 1960s and 1970s, followed by the intelligent tutoring systems (ITSs) in the 1980s and 1990s. The 1990s ushered in the Internet, which emerged as a new form of technology, leading to the growth of computer-supported collaborative learning (CSCL) and research about CSCL. Towards the end of the twentieth century, various forms of Web 2.0 
technologies, including digital media production tools, social media and social networking tools, mobile devices, and online learning technologies emerged and became popular. In addition, there are also many other forms of digital technologies in the twenty-first century, such as augmented reality, virtual reality, and cloud computing (Reiser, 2012). Such evolution represents a paradigm shift in educational technologies, which prompts us to examine the deeper relationships between technology affordances and the possibilities of learning from versus learning with computers.

A CAI system is a programmed instruction that presents tasks to be performed with increasing complexity to learners in a stimulus-response context, in which immediate correction of responses is provided. Through repetitive drills and practice, desirable behaviours are reinforced, and students learn from the CAI cognitive tool. ITSs were designed with the premise that human cognition is a process of information processing involving complex thinking, which can be modelled by a computer system to shape learners' thinking (Koschmann, 1996; Lajoie, 2000). Compared with the CAI paradigm, ITSs provide customised, canned feedback to learners based on learners' responses. However, ITSs are still limited to knowledge domains in which they can deliver procedural knowledge and skills in a rule-governed, well-structured manner but are still incapable of modelling the full complexity of human cognition (Ge, Law, \& Huang, 2012; Shute \& Psotka, 1994). In the ITS paradigm, learners' choices are still limited. As such, CAI and ITSs do not provide much room for learners to learn with technology.

The era of the 1990s witnessed a transformation from individual computers to networking technologies. Technology advancement promoted the notion of CSCL and the development of technology systems (collaboration platforms and tools) to support CSCL (e.g., Computer Supported Intentional Learning Environments, Scardamalia \& Bereiter, 1994). Representing a paradigm shift from individual use to collaborative use of computers by a group of individuals, CSCL posits that "computers can be used to facilitate, augment, and even redefine interactions among members of a work group" (Koschmann, 1994, p. 219). Within CSCL environments, learners are not alone in their cognitive and metacognitive endeavours, but rather share their individual thinking, reflection, understanding, and interpretations with others (Resnick, 1991; Salomon, 1993) in a social and cultural context (Brown, Collins, \& Duguid, 1989). More knowledgeable peers can scaffold less knowledgeable ones in their zone of proximal development (Vygotsky, 1978) through guidance and modelling and the use of cognitive tools (Collins, Brown, \& Newman, 1989) within a community of learners to achieve common goals (Wenger, 1998).

The emergence of Web 2.0 technologies in the 2000s have further extended the functionalities, modalities, and capabilities of CSCL technologies. Web 2.0 technologies (Cormode \& Krishnamurthy, 2008), a term coined around 2004 (Greenhow, Robelia, \& Hughes, 2009; Solomon \& Schrum, 2007), refers to a variety of web-based technologies that enable user-generated content, including social media tools (e.g., Facebook, Twitter, YouTube, Instagram, and Snapchat, as well as various podcasts and videocast tools), self-reflection tools (e.g., blogs), and knowledge co-construction tools (e.g., wikis). These tools enable and encourage users to generate their own content, such as postings and comments in text or visual format (Cormode \& Krishnamurthy, 2008; Solomon \& Schrum, 2007), online discussion forums, and virtual learning communities. Users of Web 2.0 technologies are both consumers and creators of the web-based content. Web 2.0 technologies encourage participation, sharing, and interaction with users within a community (Solomon \& Schrum, 2007), fostering a sense of belonging, relationship building, and identity development (Lave \& Wenger, 1991; Wenger-Trayner \& Wenger-Trayner, 2015).

\section{Cognitive tools in a traditional conception: A missing gap}

The existing literature on cognitive tools focuses on supporting learners' cognition and metacognition and shows an evolution from the "learning from" to the "learning with" paradigm. Pea (1985) underlined how cognitive tools should be viewed as tools to improve the quality of cognition and learning by extending the boundaries of cognition and redefining learning, instead of as simply amplification tools. Salomon et al. (1991) argued that computers should be used as intelligent partners, with whom students engage mindfully towards achieving a learning goal. Derry and Lajoie (1993) and Lajoie (2000) contended that cognitive tools could be utilised as scaffolding tools to support cognition and metacognition at both individual and social levels. They are typically needed by novices and provided by experts in apprenticeship models within certain social contexts or situations (Derry \& Lajoie, 1993). Despite the emphasis on using cognitive tools as intellectual partners by the "learning with" proponents, as opposed to as tutors by the "learning from" proponents, we can see that the previous work was invariably limited to the use of cognitive tools to foster 
cognition and metacognition, individually and socially. However, motivation, a critical part of human learning, is not addressed in the literature of cognitive tools, which leaves a gap for us to investigate. This study is an effort to address that need.

\section{Motivational and social dimensions of cognitive tools}

The question explored in this study is "How do emerging technologies serve as cognitive tools to scaffold learning through providing social and motivational support?" First of all, we need to examine two elements: (a) social and motivational support, and (b) technology affordances. We need to understand what motivational factors are involved in cognitive tools, and what technology affordances enable support for social and motivational dimensions. For motivational factors, we turn to self-determination theory (SDT) (Deci \& Ryan, 1985) for theoretical support.

\section{Basic psychological needs: Autonomy, competence, and relatedness}

Motivation is a driving force for learning. It concerns everything related to activation and intention, such as energy, direction, and persistence. Historically, motivation has been studied as a singular construct (Ryan \& Deci, 2000a), without examining the underlying sources of motivation, either external regulation (i.e., extrinsic motivation) or self-motivation (i.e., intrinsic motivation). Deci and Ryan (1985) took steps to identify various factors driving a human being to act, including both internal factors (e.g., basic psychological needs) and external factors (e.g., self-regulation of extrinsic motivation), which they developed into SDT. According to SDT (Deci \& Ryan, 1985), human beings have three basic psychological needs: autonomy, competence, and relatedness. Autonomy refers to the need for being free from any kind of restriction or control that would force an individual's behaviours towards a certain direction (Ryan \& Deci, 2000a, 2000b). Autonomous individuals have the choice, control, or freedom to determine, monitor, and self-regulate their own behaviours and set their own goals (Pintrich, 1999; Zimmerman, 2002). Emerging technologies (e.g., Web 2.0) provide a variety of choices and autonomy to engage individuals in self-regulated learning activities. Competence refers to the need for feeling capable in performing a particular task when individuals are challenged (Ryan \& Deci, 2000a, 2000b). It is about believing in one's capability to achieve a particular task or outcome given the autonomy to perform the task. Relatedness is the need for feeling a sense of belonging to a group or community and receiving social and emotional support from others, which is required by the environmental conditions for autonomous and intrinsic motivation to occur in individuals (Ryan \& Deci, 2000a, 2000b). Emerging technologies can support collaboration and help to build a community of learners and a sense of belonging through shared interests and relationships. In the following subsection, we made a closer examination of specific affordances of emerging technologies that can serve as cognitive tools through supporting motivation and engagement.

\section{Emerging technologies: Affordances for social and motivational support}

A wide variety of emerging technologies have affordances to enhance social connections, encourage discourse, promote peer interactions, and engage learners. These technologies may include tools that support self-reflection (e.g., blogs), social interactions (e.g., discussion forums), and knowledge coconstruction and co-building (e.g., wikis, Google collaboration tools). They may also involve various modalities (e.g., podcasts, vodcasts, videos). Social media and networking sites (e.g., Facebook and Twitter) have also emerged to become powerful tools to support motivation, social interactions, and community building. Online collaboration can also take the form of massive multiplayer online games (e.g., Eseryel, Law, Ifenthaler, Ge, \& Miller, 2014), in which social interactions are no longer restricted by text, but are rather achieved through activities immersing participants in a situated cultural context, with individual players adopting the roles of particular game characters and completing problem-solving tasks with a high fidelity in a more authentic contextual environment (e.g., virtual reality, augmented reality) (Dede, 2009; Gee, 2007; Wang, Kim, \& Shute, 2013). Various studies have shown that these technologies have the affordances to support not only cognition and metacognition, but also motivation and engagement by satisfying human needs, which include, but are not limited to, a sense of community, a sense of belonging and/or togetherness, identity development, and collaboration with others (e.g., Baker \& Moore, 2008; Dawson, 2006; Deng \& Yuen, 2011). Although some technological tools have the capability to provide individualised cognitive support through video feedback (e.g., Griffiths \& Graham, 2009; Henderson \& Phillips, 2015; McCarthy, 2015; West \& Turner, 2016), others provide social and emotional support through social interactions (e.g., Deng \& Yuen, 2011; Dickey, 2004; Glogoff, 2005; Hall \& Davison, 2007; 
Jung, Song, \& Vorderer, 2012), social networking (e.g., Ciampa \& Gallagher, 2015; Loving, Schroeder, Kang, Shimek, \& Herbert, 2007; Luehmann \& Tinelli, 2008; West, Wright, Gabbitas, \& Graham, 2006), and creativity, innovation, and user-generated content (e.g., Alexander \& Levine, 2008; Ducate \& Lomicka, 2008; Lund, 2008).

In the subsequent sections, we describe the method and procedure used for the literature review to provide evidence for the possibility of using various emerging technologies as cognitive tools in support of motivation and engagement.

\section{Method}

We employed a targeted literature review (i.e., focused literature review) method (Huelin, Iheanacho, Payne, \& Sandman, 2015) to analyse the literature on the affordances of emerging technologies in support of autonomy, competence, and relatedness. This kind of literature review is used to provide an informative (rather than all-inclusive) review on a particular theme or issue (Huelin et al., 2015). The following databases were searched for full-text, English, peer-reviewed research publications on the relevant themes: EBSCO Collection, ERIC, JSTOR, ProQuest, ScienceDirect (Elsevier Science), Springer, and Wiley Online Library. We used keywords consisting of a construct associated with motivation (e.g., motivation self-determination), or a term associated with psychological need (e.g., autonomy, competence, or relatedness), and a type of technology (e.g., games, virtual reality, wikis). Examples of keyword combinations include "relatedness Facebook", "autonomous motivation blogosphere," "social media selfdetermination", "wikis collaboration", "need satisfaction games", "social connectedness Twitter", "motivation web 2.0", "motivation digital technologies," and "basic needs social networking". Next, we screened the initial results of the search outputs by browsing through the titles. If a research article matched the keywords, we examined the abstracts for further screening. If the abstract of an article provided research findings about how a basic human need (e.g., relatedness) was satisfied by the use of any type of emerging technology, it was recorded as one with empirical evidence, which was thus saved for examination at the full-text level. Of all the articles gathered for full-text review, 21 articles were categorised in the area of autonomy, 17 articles in the area of competence, and 23 articles in the area of relatedness. Some articles fit more than one category. We organised the categorised articles in a spreadsheet to be further annotated and analysed. As a result, 12 articles of empirical research were included in the final literature analysis (see Table 1).

Table 1

Literature search output for articles with empirical evidence about emerging technologies supporting autonomy, competence, and relatedness

\begin{tabular}{|c|c|c|}
\hline Reference & Basic human need & Emerging technology \\
\hline (1) Akbari, Pilot, \& Simons, 2015 & Autonomy & Social networking sites (Facebook) \\
\hline (2) Choi, Noh, \& Park, 2014 & Autonomy & $\begin{array}{l}\text { Smartphone apps (smoking cessation } \\
\text { apps) }\end{array}$ \\
\hline (3) Demircioglu, 2018 & $\begin{array}{l}\text { Autonomy, } \\
\text { competence }\end{array}$ & $\begin{array}{l}\text { Social media (LinkedIn, Twitter, and } \\
\text { Facebook) }\end{array}$ \\
\hline $\begin{array}{l}\text { (4) Grieve, Indian, Witteveen, } \\
\text { Tolan, \& Marrington, } 2013\end{array}$ & Relatedness & Social networking sites (Facebook) \\
\hline (5) Hafner \& Miller, 2011 & Autonomy & $\begin{array}{l}\text { Video technologies (digital video } \\
\text { production) }\end{array}$ \\
\hline (6) Kramer \& Kruskar, 2017 & Autonomy & Web 2.0 technologies (blogosphere) \\
\hline (7) Rogers, 2017 & $\begin{array}{l}\text { Autonomy, } \\
\text { competence, } \\
\text { relatedness }\end{array}$ & Gaming technologies (video games) \\
\hline $\begin{array}{l}\text { (8) Ryan, Rigby, \& Przybylski, } \\
2006\end{array}$ & $\begin{array}{l}\text { Autonomy, } \\
\text { competence, } \\
\text { relatedness }\end{array}$ & Gaming technologies (video games) \\
\hline (9) Park \& Lee, 2014 & Relatedness & Social networking sites (Facebook) \\
\hline $\begin{array}{l}\text { (10) Peng, Lin, Pfeiffer, \& Winn, } \\
2012\end{array}$ & $\begin{array}{l}\text { Autonomy, } \\
\text { competence }\end{array}$ & Gaming technologies (video games) \\
\hline (11) Sinclair \& Greeve, 2017 & Relatedness & Social networking sites (Facebook) \\
\hline (12) Wang, 2014 & Competence & Web 2.0 technologies (Wikis) \\
\hline
\end{tabular}




\section{Results: Motivational and social support of emerging technologies as cognitive tools}

Technologically-enhanced social interactions do not directly enhance students' learning outcomes. However, with common learning goals and cognitive tools, technologically-enhanced learning communities can help fulfill the human psychological needs of autonomy, competence, and relatedness in students, and therefore enhance students' self-determined motivation to learn. This enhanced motivation could further elevate students' cognitive engagement, quantitatively and qualitatively, during the learning process. In the following sections, framed with the lens of SDT, we discuss the mediating socialmotivational effects of emerging technologies as cognitive tools on students' cognitive processes during learning.

\section{Supporting autonomy with cognitive tools}

A revolutionary feature of Web 2.0 is that the users are no longer mere information receivers, but also participants and contributors. Such emerging technologies provide students with autonomy in their learning endeavours (Lan, 2018) and enable them to express their thoughts and share knowledge and experiences in the social space at free will. One group of such technologies that can boost learners' autonomy is social networking sites, such as Facebook. Facebook is a social platform through which individuals can maintain existing ties and develop new social ties with people outside their network through postings of text, images, or video (Greenhow \& Robelia, 2009). It serves as a social platform that enables individuals to express their opinions and emotions. Facebook users interact with each other through simple actions such as liking and disliking each other's postings, and they can also make comments and engage in synchronous communications via chats (Hughes et al., 2012). Several empirical studies have shown that Facebook boosts learner autonomy by serving as an online social network tool. For example, Akbari et al. (2015) compared two groups of $\mathrm{PhD}$ students who studied English in either a Facebook study group or a traditional language classroom setting. The Facebook group reported a higher degree of autonomy than their peers in the traditional English classroom, with more interactions and choices of a wide variety of resources (e.g., Wikipedia, Google, videos, online tools), regarding their language learning and performance preferences (Akbari et al., 2015). In addition, learners had the freedom to participate in and carry out the assigned activities and tasks at their convenience in terms of time and space (Akbari et al., 2015). Such social networking sites provide positive social environments where supportive conversations and resources and knowledge sharing could easily take place, and thus act as co-knowledge construction cognitive tools or mindtools (Jonassen \& Carr, 2000). It is possible that the satisfaction gained from the need for autonomy mediated by Web 2.0 capability as well as the social aspects of Facebook enhanced the learners' intrinsic motivation and consequently promoted their cognitive engagement and processing during learning, which might have contributed to the higher achievement result by the Facebook group than the non-Facebook group (Akbari et al., 2015).

Other Web 2.0 technologies that can fulfill the basic human need for autonomy are blogs, podcasts, and Twitter. The autonomy affordances of these technologies create opportunities for conversations and intellectual exchange between the bloggers (in this case, students) and their readers (fellow students). These social-motivational features enable these emerging technologies to afford conversation and co-knowledge construction mindtool functions (Jonassen \& Carr, 2000) for cultivating learners' higher-order thinking skills and competence (Dennen, 2014; Gray, Thompson, Sheard, Clerehan, \& Hamilton, 2010; Oravec, 2002; Williams \& Jacobs, 2004). In a longitudinal study, Kramer and Kusurkar (2017) created a sciencewriting blog project where the students engaged in the real-world project as professional biologists. The students had the autonomy to determine which topic they would work on within the subject of cell-biology, how they would design and organise their blogs, and how they would communicate with each other and with their potential readers. The data collected over the 4 years indicated that the freedom of choice afforded by blogging helped to promote the students' sense of autonomy, which in turn enhanced their ability to self-regulate their learning during the team-based science projects.

Another example of a Web 2.0 emerging technology functioning as a cognitive tool to engage learners is podcasts or YouTube. In an English language learning environment, a group of undergraduate science students collaboratively produced a digital video project of scientific documentaries, which they presented 
in class and shared online via YouTube (Hafner \& Miller, 2011). The learners reported that the project helped them develop ownership of their learning, enabled them to work independently as individuals, and make their own decisions as a group. This digital video project in turn engaged the students in a knowledge construction cognitive process (Jonassen \& Carr, 2000) at a deeper conceptual level, mediated by the increased autonomy-related motivation and enabled by the video-making technology.

\section{Supporting competence with cognitive tools}

Competence, one of the three critical factors for human needs, also influences intrinsic motivation and cognitive engagement for learning. An empirical study showed how wiki technology promoted competence through creating a common virtual space in which individuals collaborated with one another (Parker \& Chao, 2007). The co-construction feature of the technology makes the division of labour viable and collective intelligence visible, which falls into the category of knowledge co-construction mindtools (Jonassen \& Carr, 2000). This cognitive affordance was also boosted by the participants' increased sense of competence and thus their motivation to stay on task. Wang (2014) reported a group of learners utilising Wikispaces (http://www.wikispaces.com) as a platform to collaborate in an English-as-a-foreign-language writing project. The majority of the participants reported that wikis enhanced both their motivation to learn English and their confidence to use English. Their experience was partially attributed to the students receiving positive feedback from others through the wiki platform, which helped to improve their writing performance. Such positive experience boosted the students' efficacy in performing a particular task as well as fulfilling their need for competence, which in turn led to higher motivation (Ryan \& Deci, 2000a, 2000b).

Some researchers have tried using social media tools, such as Twitter and Facebook, to promote learners' perceived competence (He, Gu, Wu, Zhai, \& Song, 2017). For example, Demircioglu (2018) investigated how using social media affected employees' job satisfaction through fulfilling their psychological needs. It was found that the government employees who used social media tools for their work purposes had higher levels of perceived competence as well as autonomy, which in turn led to higher job satisfaction. Social media tools used in such a case can be regarded as cognitive tools.

Video games have also been used for educational purposes to improve motivation and learning outcomes (Hanghøj, Lieberoth, \& Misfeldt, 2018). Video games offer promising features that can potentially enhance learner motivation and learning quality (Mayer, 2015). The motivational affordance of video games occurs most likely through promoting a sense of competence among learners (Ryan et al., 2006), which in turn increases their time on tasks and a desire to engage at deeper level of cognitive processing during learning. Certain features, attributes, and affordances of video or digital games, such as incremental levels of achievement, real-time feedback and hints, and user controls, fulfill the need for competence. Such perceived competence increases learners' motivation to engage in the cognitive tasks to be completed. More importantly, video games often provide players with immediate feedback during the course of their actions. This feedback helps to guide the players throughout the game and provides just-in-time scaffolding for them to confidently develop their competence (Ryan et al., 2006). Peng et al. (2012) found that video games featuring increasing challenges, performance feedback, and virtual rewards served to fulfill the players' basic need for competence in comparison with those video games that did not offer such features. In these examples, video games are clearly a type of cognitive tools that have strong affordances for cognitive and motivational support.

\section{Supporting relatedness with cognitive tools}

The social aspect of emerging technologies has particularly effective motivational effects in supporting the basic psychological need for relatedness. Web 2.0 technologies, social networking sites, and other digital technologies provide various opportunities for individuals to interact socially, communicate, and collaborate in virtual spaces (Harris \& Rea, 2009). People naturally seek support from other individuals who share common interests, concerns, passions, or experiences to which they can relate. The sense of relatedness generates motivation for actions (Ryan \& Deci, 2000a). Emerging technologies have empowered us in fulfilling the need for relatedness by increasing our sense of social belonging, social connectedness, community feeling, and social support as "our relationships are increasingly mediated by technology" (Peters, Calvo, \& Ryan, 2018, p.6). 
Autonomous and intrinsic motivation can be fostered by social and environmental conditions (Ryan \& Deci, 2000b). Facebook, as one of the most visited social networking sites today, can potentially offer these positive social and environmental conditions which enable individuals to make virtual connections with people they know and have real-life connections (Boyd \& Ellison, 2007; Horzum \& Demirhan, 2017; Valkenburg \& Peter, 2009). The sense of social connection and belongingness motivates people to stay connected with other participants, tasks, or activities because of the inter-supportive relationships. As a result, the enhanced motivation to stay connected could encourage a higher level of cognitive processing during learning when social networking sites are used as a motivationally enhanced cognitive tool in fulfilling the conversational and knowledge co-construction functions, which Jonassen and Carr (2000) advocated. In two studies, Grieve et al. (2013) investigated if Facebook could be used as a social platform to foster belongingness and connectedness as opposed to real, face-to-face social life, and if so, how it might contribute to human psychological well-being. In their first study, Grieve et al. (2013) administered social connectivity scales to measure the participants' self-perceptions of both offline and online social connectedness. They found that social connectedness could be gained from a social networking site like Facebook. In the second study, Grieve et al. (2013) administered two additional scales to measure subjective well-being, depression, and anxiety. They found that Facebook social connectedness positively correlated with well-being and negatively correlated with depression and anxiety. Similarly, Park and Lee (2014) studied the psychological state of motivation in using Facebook and found a positive association between college students' use of Facebook and their sense of belonging on campus. Furthermore, Sinclair and Grieve (2017) found that older adults, similar to their younger counterparts, could also obtain personal satisfaction of belonging and affiliation through social connectedness from their use of Facebook.

\section{Discussion and conclusion}

The purpose of this study was to review what has been achieved in the research on computers as cognitive tools in the past four decades in order to identify gaps in the literature and move forward in the research of educational technologies. In this article, we have reviewed the rise of the research on computers as cognitive tools, with specific discussion on the central issues surrounding the concept of cognitive tools: learning from (amplification view of technology) versus learning with (constructivist view of technology). The different perspectives of behaviourism and constructivism on the role of technology reflect different views on memory, learning, instruction, and instructional design. A historical review of cognitive tools reveals a gradual paradigm shift from learning from to learning with as emerging technologies have advanced to enable these changes.

With the shift from behaviourist teacher-centred instruction to constructivist student-centred learning, we see a gradual evolution in the conceptualisation of cognitive tools, following the vision shared by Jonassen (1995) and Lajoie and Derry (1993). Their views of cognitive tools emphasise their cognitive functionalities in supporting the knowledge construction of learners, focusing on higher-order thinking skills as learning outcomes, such as critical thinking, metacognition, problem-solving, and decision making. The rise of the CSCL paradigm in the mid- and late 1990s has helped further the concept of knowledge construction by increasing the emphasis on communities of learners and practice (Scardamalia \& Bereiter, 1994). Overall, the field is witnessing an increasing use and integration of emerging technologies to scaffold learners in their pursuit of learning goals with not only more tools and resources, but also choices and opportunities for social interactions and motivational support.

Our research has compelled us to re-examine the role of cognitive tools in connection with the added affordances and value of emerging technologies in providing social and motivational support. We have found ample empirical evidence demonstrating the positive effects of emerging technologies in providing social and motivational support. In this article, we have reviewed a collection of studies, using the SDT framework, that is, autonomy, competence, and relatedness. We have specifically discussed the social and motivational functionalities and affordances of cognitive tools in the context of current emerging technologies. The existing literature shows a lack of research on the social and motivational dimension in the context of cognitive tools and specific exploration of cognitive tools in addressing of interrelationships between motivational and social support and cognition and metacognition.

The findings from this targeted literature review, although preliminary, have helped us to conceptualise the construct of cognitive tools by recognising their value in providing social and motivational scaffolding. The findings have also help to examine how such scaffolding leads to deeper cognitive engagement and 
thus deeper learning. It suggests that cognitive tools, in light of emerging technologies, can also provide social and motivational support to satisfy learners' psychological needs, which would most likely generate an internal driving force to enhance the learning experience and improve learning outcomes. This research has implications for instructional design, learning, and instruction. It will help educators to understand how to integrate emerging technologies appropriately and effectively to support learning in various dimensions, such as cognition, metacognition, motivation, and social support.

As we worked on this study, we noticed that the research on cognitive tools had decreased over the past two decades. As emerging technologies have become an integral part of education, we cannot assume that technologies have been used appropriately as cognitive tools to scaffold higher-order thinking and motivate learners in all cases, despite the affordances and capabilities of Web 2.0 technologies. It is therefore paramount to continue this line of research. We hope that by exploring the social and motivation dimensions of the cognitive tools, inquiry on cognitive tools may continue in a new and expanded direction. We encourage future research that investigates the interrelationships among cognition, motivation, and engagement in the context of emerging technologies, particularly technology affordances, perceived value and use of technology, and epistemic beliefs (Eseryel et al., 2014; Ge, Yang, Liao, \& Wolfe, 2015). Due to the space limit, we have not been able to classify different types, forms, and modalities of up-to-date emerging technologies used for education, such as massively multiplayer online games, augmented reality, and virtual reality, and map them to the different psychological needs to understand how these technologies have different technological features, characteristics, and affordances to support social and motivational dimensions. This is an area we will investigate in the future.

\section{References}

Akbari, E., Pilot, A., \& Robert-Jan Simons, P. (2015). Autonomy, competence, and relatedness in foreign language learning through Facebook. Computers in Human Behavior, 48, 126-134.

https://doi.org/10.1016/j.chb.2015.01.036

Alexander, B. \& Levine, A. (2008). Web 2.0 storytelling: Emergence of a new genre. EDUCAUSE Review, 43(6), 40-56. Retrieved from https://er.educause.edu/articles/2008/10/web-20-storytellingemergence-of-a-new-genre

Baker, J. R., \& Moore, S. M. (2008). Blogging as a social tool: A psychosocial examination of the effects of blogging. CyberPsychology \& Behavior, 11(6), 747-749. https://doi.org/10.1089/cpb.2008.0053

Boyd, D. M., \& Ellison, N. B. (2007). Social network sites: Definition, history, and scholarship. Journal of Computer-Mediated Communication, 13(1), 210-230. https://doi.org/10.1111/j.1083$\underline{6101.2007 .00393 . \mathrm{x}}$

Brown, J., Collins, A., \& Duguid, P. (1989). Situated cognition and the culture of learning. Educational Researcher, 18(1), 32-42. Retrieved from http://www.jstor.org/stable/1176008

Choi, J., Noh, G.-Y., \& Park, D.-J. (2014). Smoking cessation apps for smartphones: Content analysis with the self-determination theory. Journal of Medical Internet Research, 16(2), e44. https://doi.org/10.2196/jmir.3061

Ciampa, K., \& Gallagher, T. L. (2015). Blogging to enhance in-service teachers' professional learning and development during collaborative inquiry. Educational Technology Research and Development, 63(6), 883-913. https://doi.org/10.1007/s11423-015-9404-7

Collins, A., Brown, J. S., \& Newman, S. E. (1989). Cognitive apprenticeship: Teaching the crafts of reading, writing, and mathematics. In L. B. Resnick (Ed.), Knowing, learning, and instruction: Essays in honor of Robert Glaser (pp. 453-494). Hillsdale, NJ: Erlbaum.

Cormode, G., \& Krishnamurthy, B. (2008). Key differences between Web 1.0 and Web 2.0. First Monday, 13(6). https://doi.org/10.5210/fm.v13i6.2125

Dawson, S. (2006). A study of the relationship between student communication interaction and sense of community. The Internet and Higher Education, 9(3), 153-162. https://doi.org/10.1016/j.iheduc.2006.06.007

Deci, E. L., \& Ryan, R. M. (1985). Intrinsic motivation and self-determination in human behavior. New York, NY: Plenum.

Deci, E. L., \& Ryan, R. M. (2000). The "what" and "why" of goal pursuits: Human needs and the selfdetermination of behavior. Psychological Inquiry, 11(4), 227-268. https://doi.org/10.1207/S15327965PLI1104_01

Dede, C. (2009). Immersive interfaces for engagement and learning. Science, 323(66), 66-69. https://doi.org/10.1126/science.1167311 
Demircioglu, M. A. (2018). Examining the effects of social media use on job satisfaction in the Australian public service: Testing self-determination theory. Public Performance \& Management Review, 41(2), 300-327. https://doi.org/10.1080/15309576.2017.1400991

Deng, L., \& Yuen, A. H. K. (2011). Towards a framework for educational affordances of blogs. Computers \& Education, 56(2), 441-451. https://doi.org/10.1016/j.compedu.2010.09.005

Dennen, V. P. (2014). Becoming a blogger: Trajectories, norms, and activities in a community of practice. Computers in Human Behavior, 36, 350-358. https://doi.org/10.1016/j.chb.2014.03.028

Derry, S. J., \& Lajoie, S. P. (1993). A middle camp for (un)intelligent instructional computing: An introduction. In S. P. Lajoie \& S. J. Derry (Eds.), Computers as cognitive tools (pp. 1-11). Hillsdale, NJ: Erlbaum.

Dickey, M. (2004). The impact of web-logs (blogs) on student perceptions of isolation and alienation in a web-based distance-learning environment. Open Learning, 19(3), 279-291. https://doi.org/10.1080/0268051042000280138

Ducate, L. C., \& Lomicka, L. L. (2008). Adventures in the blogosphere: From blog readers to blog writers. Computer Assisted Language Learning, 21(1), 9-28. https://doi.org/10.1080/09588220701865474

Eseryel, D., Law, V., Ifenthaler, D., Ge, X., \& Miller, R. B. (2014). An investigation of the interrelationships between motivation, engagement, and complex problem solving in game-based learning. Educational Technology \& Society, 17(1), 42-53. Retrieved from https://www.jstor.org/stable/jeductechsoci.17.1.42

Ge, X., Law, V., \& Huang, K. (2012). Diagnosis, supporting, and fading: A scaffolding design framework for adaptive e-learning systems. In $\mathrm{H}$. Wang (Ed.), Interactivity in e-learning: Case studies and frameworks (pp. 116-142). Hershey, PA: IGI Global.

Ge, X., Yang, Y. J., Liao, L., \& Wolfe, E. G. (2015). Perceived affordances of a technology enhanced active learning classroom in promoting collaborative problem solving. In P. Isaías, P., J. M. Spector, D. Ifenthaler, \& D. G. Sampson (Eds.), E-Learning systems, environments and approaches: Theory and implementation (pp. 305-322). New York, NY: Springer.

Gee, J. P. (2007). Learning and games. In K. Salen (Ed.), The ecology of games: Connecting youth, games, and learning (pp. 21-40). Cambridge, MA: MIT Press.

Glogoff, S. (2005). Instructional blogging: Promoting interactivity, student-centered learning, and peer input. Innovate: Journal of Online Education, 1(5), art. 3. Retrieved from https://nsuworks.nova.edu/innovate/voll/iss5/3/

Gray, K., Thompson, C., Sheard, J., Clerehan, R., \& Hamilton, M. (2010). Students as Web 2.0 authors: Implications for assessment design and conduct. Australasian Journal of Educational Technology, 26(1), 105-122. https://doi.org/10.14742/ajet.1105

Greenhow, C., \& Robelia, B. (2009). Informal learning and identity formation in online social networks. Learning, Media \& Technology, 34(2), 119-140. https://doi.org/10.1080/17439880902923580

Greenhow, C., Robelia, B., \& Hughes, J. E. (2009). Learning, teaching, and scholarship in a digital age: Web 2.0 and classroom research: What path should we take now? Educational Researcher, 38(4), 246-259. https://doi.org/10.3102/0013189X09336671

Grieve, R., Indian, M., Witteveen, K., Tolan, G. A., \& Marrington, J. (2013). Face-to-face or Facebook: Can social connectedness be derived online? Computers in Human Behavior, 29(3), 604-609. https://doi.org/10.1016/j.chb.2012.11.017

Griffiths, M. E., \& Graham, C. R. (2009). Using asynchronous video in online classes: Results from a pilot study. International Journal of Instructional Technology and Distance Learning, 6(3), 65-76. Retrieved from http://itdl.org/Journal/Mar_09/article06.htm

Hafner, C. A., \& Miller, L. (2011). Fostering learner autonomy in English for science: A collaborative digital video project in a technological learning environment. Language Learning \& Technology, 15(3), 68-86. https://doi.org/10125/44263

Hall, H., \& Davison, B. (2007). Social software as support in hybrid learning environments: The value of the blog as a tool for reflective learning and peer support. Library \& Information Science Research, 29(2), 163-187. https://doi.org/10.1016/j.lisr.2007.04.007

Hanghøj, T., Lieberoth, A., \& Misfeldt, M. (2018). Can cooperative video games encourage social and motivational inclusion of at-risk students? British Journal of Educational Technology, 49(4), 775799. https://doi.org/10.1111/bjet.12642

Harris, A. L., \& Rea, A. (2009). Web 2.0 and virtual world technologies: A growing impact on IS education. Journal of Information Systems Education, 20(2), 137-144. Retrieved from http://jise.org/Volume20/n2/JISEv20n2p137.pdf 
He, C., Gu, J., Wu, W., Zhai, X., \& Song, J. (2017). Social media use in the career development of graduate students: The mediating role of internship effectiveness and the moderating role of Zhongyong. Higher Education, 74(6), 1033-1051. https://doi.org/10.1007/s10734-016-0107-8

Henderson, M., \& Phillips, M. (2015). Video-based feedback on student assessment: Scarily personal. Australasian Journal of Educational Technology, 31(1), 51-66. https://doi.org/10.14742/ajet.1878

Horzum, M. B., \& Demirhan, E. (2017). The role of chronotype on Facebook usage aims and attitudes towards Facebook and its features. Computers in Human Behavior, 73, 125-131. https://doi.org/10.1016/j.chb.2017.03.038

Huelin, R., Iheanacho, I., Payne, K., \& Sandman, K. (2015, May). What's in a name? Systematic and non-systematic literature reviews, and why the distinction matters. The Evidence Forum. Retrieved from https://www.evidera.com/wp-content/uploads/2015/06/Whats-in-a-Name-Systematic-and-NonSystematic-Literature-Reviews-and-Why-the-Distinction-Matters.pdf

Jonassen, D. H. (1990). Thinking technology: Toward a constructivist view of instructional design. Educational Technology, 30(9), 32-34. Retrieved from https://www.learntechlib.org/p/170736/

Jonassen, D. H. (1991). Objectivism versus constructivism: Do we need a new philosophical paradigm? Educational Technology Research and Development, 39(3), 5-14. https://doi.org/10.1007/BF02296434

Jonassen, D. H. (1995). Computers as cognitive tools: Learning with technology, not from technology. Journal of Computing in Higher Education, 6(2), 40-73. https://doi.org/10.1007/BF02941038

Jonassen, D. H. (1996). Computers in the classroom: Mindtools for critical thinking. Upper Saddle River, NJ: Prentice Hall.

Jonassen, D. H. (2000). Revisiting activity theory as a framework for designing student-centered learning environments. In D. H. Jonassen \& S. M. Land (Eds.), Theoretical foundations of learning environments (pp. 89-121). Mahwah, NJ: Erlbaum.

Jonassen, D. H., \& Carr, C. S. (2000). Mindtools: Affording multiple knowledge representations for learning. In S. P. Lajoie (Ed.), Computers as cognitive tools: No more walls (Vol. 2, pp. 165-196). Mahwah, NJ: Erlbaum.

Jonassen, D. H., \& Reeves, T. C. (1996). Learning with technology: Using computers as cognitive tools. In D. H. Jonassen (Ed.), Handbook of research for educational communications and technology (pp. 693-719). New York, NY: Simon \& Schuster Macmillan.

Jung, Y., Song, H., \& Vorderer, P. (2012). Why do people post and read personal messages in public? The motivation of using personal blogs and its effects on users' loneliness, belonging, and well-being. Computers in Human Behavior, 28(5), 1626-1633. https://doi.org/10.1016/j.chb.2012.04.001

Kim, M. C. (2012). Revisiting cognitive tools: Shifting the focus to tools-in-use. Educational Technology, 52(4), 14-24. Retrieved from https://www.jstor.org/stable/44430054

Koschmann, T. (1996). CSCL: Theory and practice of an emerging paradigm. Mahwah, NJ: Erlbaum.

Koschmann, T. D. (1994). Toward a theory of computer support for collaborative learning. The Journal of the Learning Sciences, 3(3), 219-225. https://doi.org/ 10.1207/s15327809jls0303 1

Kramer, I. M., \& Kusurkar, R. A. (2017). Science-writing in the blogosphere as a tool to promote autonomous motivation in education. The Internet and Higher Education, 35, 48-62. https://doi.org/10.1016/j.iheduc.2017.08.001

Lajoie, S. (2000). Computers as cognitive tools: No more walls (Vol. II). Mahwah, NJ: Erlbaum.

Lajoie, S., \& Derry, S. J. (1993). Computer as cognitive tools. Hillsdale, NJ: Erlbaum.

Lan, Y.-J. (2018). Technology enhanced learner ownership and learner autonomy through creation. Educational Technology Research and Development, 66(4), 859-862. https://doi.org/10.1007/s11423018-9608-8

Lave, J., \& Wenger, E. (1991). Situated learning: Legitimate peripheral participation. Cambridge, England: Cambridge University Press.

Loving, C. C., Schroeder, C., Kang, R., Shimek, C., \& Herbert, B. (2007). Blogs: Enhancing links in a professional learning community of science and mathematics teachers. Contemporary Issues in Technology and Teacher Education, 7(3), 178-198. Retrieved from https://www.learntechlib.org/p/24373/

Luehmann, A. L., \& Tinelli, L. (2008). Teacher professional identity development with social networking technologies: Learning reform through blogging. Educational Media International, 45(4), 323-333. https://doi.org/10.1080/09523980802573263

Lund, A. (2008). Wikis: A collective approach to language production. ReCALL, 20(1), 35-54. https://doi.org/10.1017/S0958344008000414 
Mayer, R. E. (2015). On the need for research evidence to guide the design of computer games for learning. Educational Psychologist, 50(4), 349-353. https://doi.org/10.1080/00461520.2015.1133307

McCarthy, J. (2015). Evaluating written, audio and video feedback in higher education summative assessment tasks. Issues in Educational Research, 25(2), 153-169. Retrieved from http://www.iier.org.au/iier25/mccarthy.pdf

Miller, G. (1956). The magical number seven, plus or minus two: Some limits on our capacity for processing information. The Psychological Review, 63, 81-97. https://doi.org/10.1037/h0043158

Oravec, J. A. (2002). Bookmarking the world: Weblog applications in education. Journal of Adolescent \& Adult Literacy, 45(7), 616-621. Retrieved from https://www.jstor.org/stable/40012246

Park, N., \& Lee, S. (2014). College students' motivations for Facebook use and psychological outcomes. Journal of Broadcasting \& Electronic Media, 58(4), 601-620. https://doi.org/10.1080/08838151.2014.966355

Parker, K. R., \& Chao, J. T. (2007). Wiki as a teaching tool. Interdisciplinary Journal of Knowledge and Learning Objects, 3, 57-72. Retrieved from http://www.ijklo.org/Volume3/IJKLOv3p057072Parker284.pdf

Pea, R. D. (1985). Beyond amplification: Using the computer to reorganize mental functioning. Educational Psychologist, 20(4), 167-182. https://doi.org/10.1207/s15326985ep2004_2

Peng, W., Lin, J.-H., Pfeiffer, K. A., \& Winn, B. (2012). Need satisfaction supportive game features as motivational determinants: An experimental study of a self-determination theory guided exergame. Media Psychology, 15(2), 175-196. https://doi.org/10.1080/15213269.2012.673850

Peters, D., Calvo, R. A., \& Ryan, R. M. (2018). Designing for motivation, engagement and wellbeing in digital experience. Frontiers in Psychology, 9, 1-15. Retrieved from https://www.frontiersin.org/articles/10.3389/fpsyg.2018.00797/full

Pintrich, P. R. (1999). The role of motivation in promoting and sustaining self-regulated learning. International Journal of Educational Research, 31(6), 459-470. https://doi.org/10.1016/S08830355(99)00015-4

Reiser, R. A. (2012). A history of instructional design and technology. In R. A. Reiser \& J. V. Dempsey (Eds.), Trends and issues in instructional design and technology (3rd ed., pp. 17-34). Boston, MA: Pearson Education.

Resnick, L. B. (1991). Shared cognition: Thinking as social practice. In L. B. Resnick, J. M. Levine, \& S. D. Teasley (Eds.), Perspectives on socially shared cognition (pp. 1-20). Washington, DC: American Psychological Association.

Rogers, R. (2017). The motivational pull of video game feedback, rules, and social interaction: Another self- determination theory approach. Computers in Human Behavior, 73, 446-450. https://doi.org/10.1016/j.chb.2017.03.048

Ryan, R. M., \& Deci, E. L. (2000a). Self-determination theory and the facilitation of intrinsic motivation, social development, and well-being. The American Psychologist, 55(1), 68-78. https://doi.org/10.1037/0003-066X.55.1.68

Ryan, R. M, \& Deci, E. L. (2000b). Intrinsic and extrinsic motivations: Classic definitions and new directions. Contemporary Educational Psychology, 25, 54-67. https://doi.org/10.1006/ceps.1999.1020

Ryan, R., Rigby, C., \& Przybylski, A. (2006). The motivational pull of video games: A selfdetermination theory approach. Motivation \& Emotion, 30(4), 347-363. https://doi.org/10.1007/s11031-006-9051-8

Salomon, G. (Ed.). (1993). Distributed cognitions: Psychological and educational considerations. New York, NY: Cambridge University Press.

Salomon, G., \& Perkins, D. N. (1989). Rocky roads to transfer: Rethinking mechanisms of a neglected phenomenon. Educational Psychologist, 24(2), 113-142. https://doi.org/10.1207/s15326985ep2402_ 1

Salomon, G., Perkins, D. N., \& Globerson, T. (1991). Partners in cognition: Extending human intelligence with intelligent technologies. Educational Researcher, 20(3), 2-9. https://doi.org/10.2307/1177234

Scardamalia, M., \& Bereiter, C. (1994). Computer support for knowledge-building communities. Journal of the Learning Sciences, 3(3), 265-283. https://doi.org/10.1207/s15327809jls0303 3

Shute, V. J., \& Psotka, J. (1994). Intelligent tutoring systems: Past, present, and future (Interim Technical Paper No. 9467077). San Antonio, TX: United States Air Force, Brooks Air Force Base. Retrieved from https://www.researchgate.net/publication/235108246_Intelligent_Tutoring_Systems_Past_Present_an d_Future 
Sinclair, T. J., \& Grieve, R. (2017). Facebook as a source of social connectedness in older adults. Computers in Human Behavior, 66, 363-369. https://doi.org/10.1016/j.chb.2016.10.003

Solomon, G., \& Schrum, L. (2007). Web 2.0: New tools, new schools. Eugene, OR: International Society for Technology in Education.

Sweller, J. (1988). Cognitive load during problem solving: Effects on learning. Cognitive Science, 12(2), 257-285. https://doi.org/10.1207/s15516709 $\operatorname{cog} 1202 \_4$

Valkenburg, P. M., \& Peter, J. (2009). Social consequences of the Internet for adolescents: A decade of research. Current Directions in Psychological Science, 18(1), 1-5. https://doi.org/10.1111/j.1467$\underline{8721.2009 .01595 . \mathrm{x}}$

Veletsianos, G. (2010). A definition of emerging technologies for education. In G. Veletsianos (Ed.), Emerging technologies in distance education (pp. 3-22). Edmonton, Canada: AU Press.

Vygotsky, L. S. (1978). Mind in society: The development of higher psychological processes. Cambridge, MA: Harvard University Press.

Wang, L., Kim, Y. J., \& Shute, V. J. (2013). “Gaming the system” in Newton's Playground. In E. Walker \& C.-K. Looi (Eds.), Proceedings of the Workshops of the 16th International Conference on Artificial Intelligence in Education (Vol. 2, pp. 85-88). Berlin, Germany: Springer-Verlag. Retrieved from http://ceur-ws.org/Vol-1009/0214.pdf

Ward, M., \& Sweller, J. (1990). Structuring effective worked examples. Cognition and Instruction, 7, 139. https://doi.org/10.1207/s1532690xci0701 1

Wenger, E. (1998). Communities of practice: Learning, meaning, and identity. Cambridge, England: Cambridge University Press.

Wenger-Trayner, E., \& Wenger-Trayner, B. (2015). Community of practice: A brief introduction. Retrieved from http://wenger-trayner.com/wp-content/uploads/2015/04/07-Brief-introduction-tocommunities-of-practice.pdf

West, J., \& Turner, W. (2016). Enhancing the assessment experience: Improving student perceptions, engagement and understanding using online video feedback. Innovations in Education \& Teaching International, 53(4), 400-410. https://doi.org/10.1080/14703297.2014.1003954

West, R., Wright, G., Gabbitas, B., \& Graham, C. (2006). Reflections from the introduction of blogs and RSS feeds into a preservice instructional technology course. TechTrends: Linking Research \& Practice to Improve Learning, 50(4), 54-60. https://doi.org/10.1007/s11528-006-0054-9

Williams, J. B., \& Jacobs, J. (2004). Exploring the use of blogs as learning spaces in the higher education sector. Australasian Journal of Educational Technology, 20(2), 232-247. https://doi.org/10.14742/ajet.1361

Zimmerman, B. J. (2002). Becoming a self-regulated learner: An overview. Theory into Practice, 41(2), 64-70. https://doi.org/10.1207/s15430421tip4102_2

Corresponding author: Xun Ge, xge@ou.edu

Please cite as: Ge, X., Turk, M., \& Hung, W. (2019). Revisiting cognitive tools from a social and motivational perspective. Australasian Journal of Educational Technology, 35(2), 39-51. https://doi.org/10.14742/ajet.4887 